\title{
The Viking Great Army in England: new dates from the Repton charnel
}

\author{
Catrine L. Jarman ${ }^{1, *}$, Martin Biddle ${ }^{2}$, Tom Higham ${ }^{3}$ \\ $\&$ Christopher Bronk Ramsey ${ }^{3}$
}

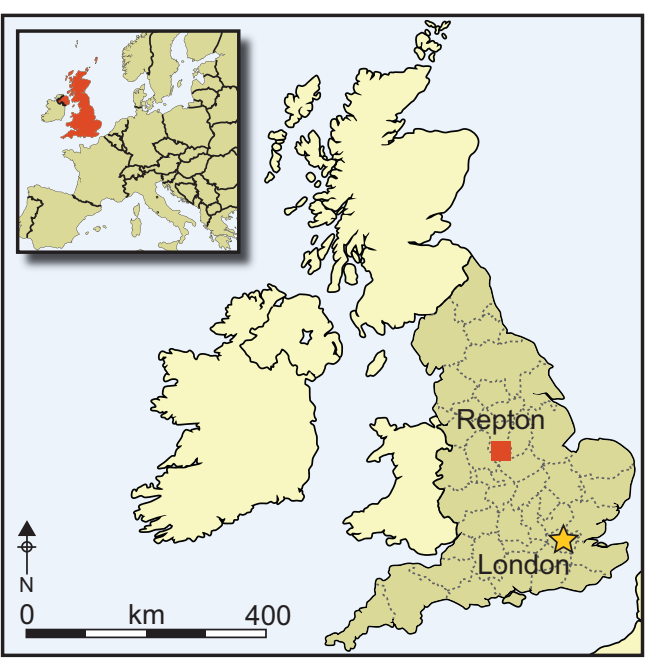

Archaeological evidence for the Viking Great Army that invaded England in $A D 865$ is focused particularly on the area around St Wystan's church at Repton in Derbyshire. Large numbers of burials excavated here in the 1980s have been attributed to the overwintering of the Great Army in AD 873874. Many of the remains were deposited in a charnel, while others were buried in graves with Scandinavian-style grave goods. Although numismatic evidence corroborated the belief that these were the remains of the Great Army, radiocarbon results have tended to disagree. Recent re-dating of the remains, applying the appropriate marine reservoir correction, has clarified the relationship between the interments, and has resolved the previous uncertainty.

Keywords: UK, Repton, Viking Age, Viking Great Army, radiocarbon dating, marine reservoir effects

\section{Introduction}

Between 1980 and 1986, investigations in the vicinity of St Wystan's church at Repton in Derbyshire (Figure 1) uncovered a charnel deposit containing the disarticulated remains of at least 264 people under a low pebble mound (Biddle \& Kjølbye-Biddle 1992, 2001). The bones were hypothesised to be those of the Viking Great Army that overwintered in Repton in AD 873-874, according to the Anglo-Saxon Chronicle (Swanton 2000). The excavators also discovered extensive evidence of a large defensive ditch and a number of furnished

\footnotetext{
Department of Archaeology and Anthropology, University of Bristol, 43 Woodland Road, Bristol BS8 IUU, UK Winchester Research Unit, 276 Banbury Road, Oxford OX2 7HA, UK

Oxford Radiocarbon Accelerator Unit, University of Oxford, Dyson Perrins Building, South Parks Road, Oxford OX1 3QY, UK

* Author for correspondence (Email: catjarman@gmail.com)
}

(C) Antiquity Publications Ltd, 2018. This is an Open Access article, distributed under the terms of the Creative Commons Attribution licence (http://creativecommons.org/licenses/by/4.0/), which permits unrestricted reuse, distribution, and reproduction in any medium, provided the original work is properly cited. 

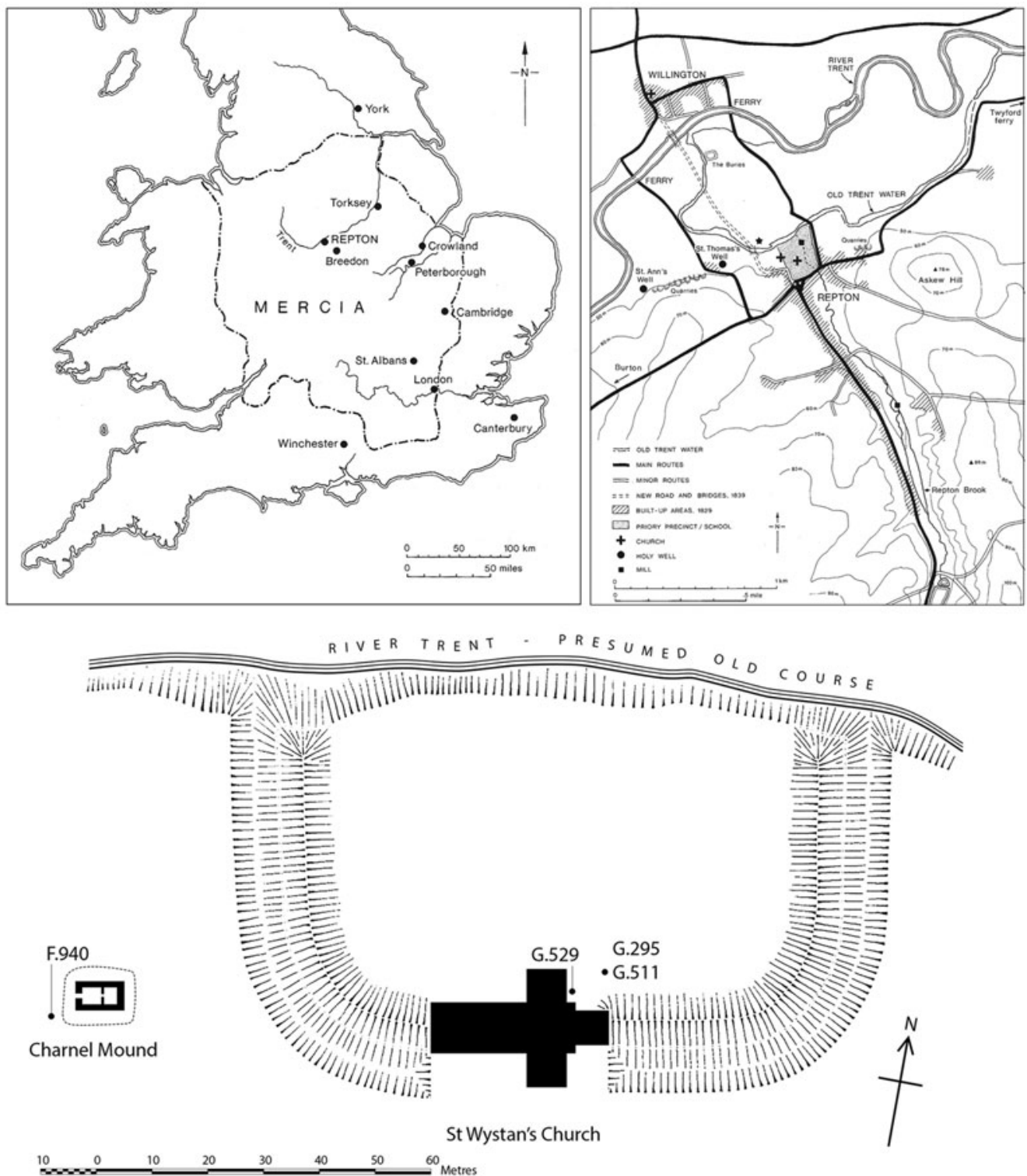

Figure 1. Location of Repton and site plan.

burials with distinctly Scandinavian-style grave goods. Numismatic evidence assigned both the charnel and the Viking graves to AD 872-75 (Biddle et al. 1986; Pagan 1986; Biddle \& Kjølbye-Biddle 1992, 2001). Radiocarbon date determinations of bone collagen from the charnel deposit, however, seemed to disagree with the archaeological findings. Although several samples were consistent with a ninth-century date, a number dated to the seventh and eighth centuries $\mathrm{AD}$, and thus seemed to belong to an earlier phase of activity (Biddle (C) Antiquity Publications Ltd, 2018 
\& Kjølbye-Biddle 2001). As a result, the identification of those buried in the charnel as members of the Great Army has been brought into question (e.g. Richards et al. 2004).

The date and identification of the Repton charnel is important for a number of reasons. Despite significant evidence for a Scandinavian presence in England in the ninth century $\mathrm{AD}$, securely identified Scandinavian inhumations, and thereby direct osteological evidence for a migrant population, are rare (Richards 2002; Redmond 2007). The nature and magnitude of Scandinavian migrations to England in the early medieval period is still disputed (e.g. Sawyer 1957; Hadley 2006; Leslie et al. 2015; Kershaw \& Røyrvik 2016). The size and nature of Great Army winter camps has been used as a proxy to estimate the size of the invading forces, but with divergent results (cf. Sawyer 1962; Hadley et al. 2016). An accurate understanding of the chronology at Repton is therefore essential for improving our knowledge in these areas.

Here we present new radiocarbon dates of bone material from Repton to elucidate the dating of the charnel deposit. We take into account marine reservoir effects (MREs) on human bone, and use contextual information with Bayesian modelling to constrain the dates further. The results show that all dated remains from the charnel deposit are consistent with a single late ninth-century event. Beyond the context of Viking Age England, the material presented here demonstrates the need to account fully for MREs, in particular when working with secondary burials or material where ${ }^{14} \mathrm{C}$ dates seem inconsistent with other forms of evidence.

\section{Background}

Excavations were carried out in Repton between 1974 and 1980 by Harold Taylor, Martin Biddle and Birthe Kjølbye-Biddle, with the initial aim of investigating the origins of the Anglo-Saxon church of St Wystan (Taylor 1989; Biddle \& Kjølbye-Biddle 1992, 2001). Repton was a significant royal and ecclesiastical centre in the Anglo-Saxon kingdom of Mercia. It was the location of a double monastery for men and women ruled by an abbess, established in the third quarter of the seventh century (Biddle \& Kjølbye-Biddle 1985). According to the Anglo-Saxon Chronicle, the Viking Great Army took up winter quarters in Repton in AD 873, driving the Mercian king Burghred into exile in Paris (Swanton 2000). A large defensive ditch abutting St Wystan's church was discovered during the excavations, and was interpreted as part of a D-shaped enclosure, using the church as a gatehouse, with the River Trent forming a natural line of defence to the north (Figure 1). Several burials with grave goods of a distinctly Scandinavian type were discovered within and around this enclosure. Most notable was a double grave of two men, of which one (G.511) was furnished with artefacts including a sword of Peterson type $\mathrm{M}$, and a silver Thor's hammer pendant (Figure 2). Strontium and oxygen isotope analysis of tooth enamel from these two individuals has demonstrated that they both grew up in a region commensurate with values expected from southern Scandinavia (Budd et al. 2004).

The mass burial of at least 264 people, largely comprised of men aged 18-45, was found beneath a mound in the vicarage garden to the west of St Wystan's church (Biddle \& Kjølbye-Biddle 1992, 2001). This charnel deposit was placed inside the eastern compartment of a partially levelled, two-celled building of seventh- to eighth-century date, 
thought to have been a chapel forming part of the Anglo-Saxon monastery. Despite the wholesale disturbance of the bones when the deposit was first uncovered in the seventeenth and early nineteenth centuries (Degg 1727;
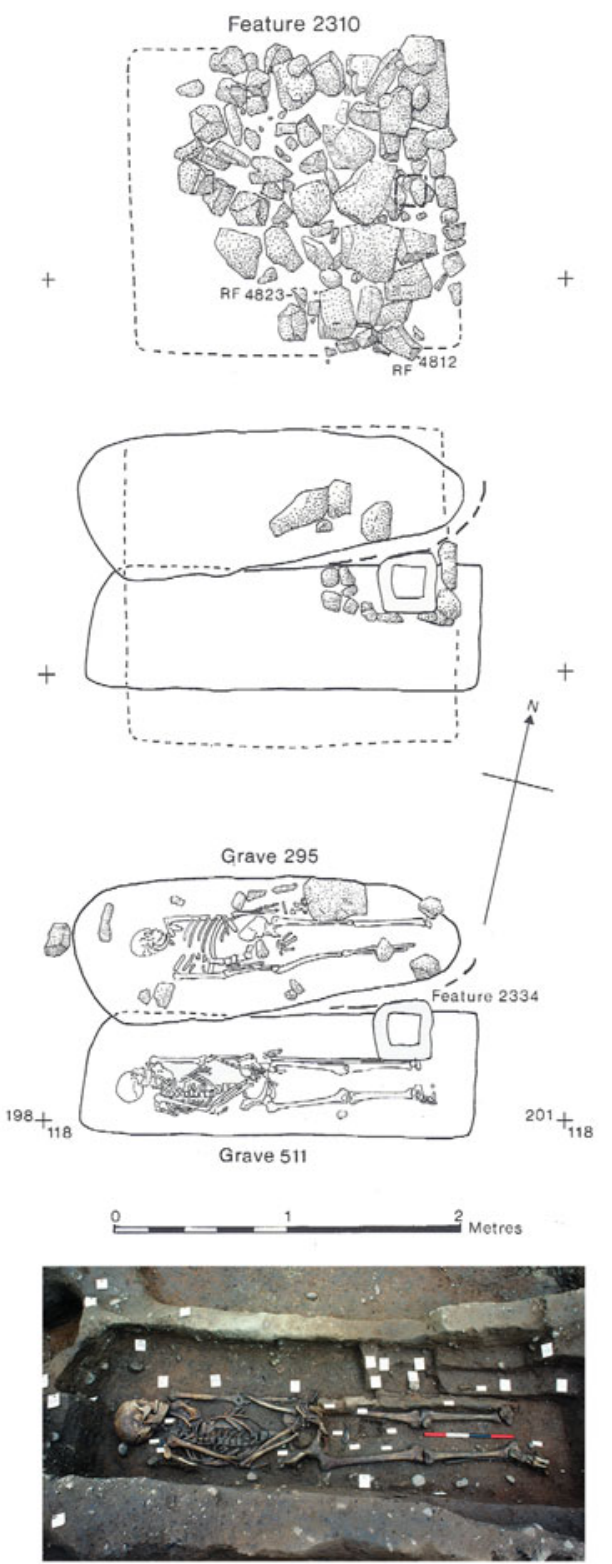

Figure 2. Plan of the double grave (G.511 and G.295); and photograph of G.511 (@ M. Biddle). Bigsby 1854), some of the long bones found in 1982 were still stacked charnelwise in position. A layer of clean red marl had been placed beneath the bones in preparation, demonstrating that deposition occurred as a single event. Artefacts found among the bones included an iron axe, two fighting knives and five silver pennies datable to AD 872-874 (Pagan 1986).

Following the closure of the mound over the bone deposit, burial continued in the area around St Wystan's from the later ninth century onwards. Importantly, a number of burials, referred to as cemetery $3 \mathrm{M}$, were cut directly into the mound itself, over the charnel deposit. Of particular significance is a grave (feature F940) found immediately outside the mound to the south-west. This contained four juveniles aged between 6 and 17, carefully arranged with a sheep jaw placed at their feet (Figure 3). A square stone setting beside the grave seems to have held a substantial marker of unknown type. The location of this grave and the deliberate arrangement of the four bodies suggest that it could have been a sacrificial deposit intended to mark the completion of the charnel mound.

In 1995, a set of 22 samples were AMS ${ }^{14} \mathrm{C}$ dated at the Van de Graaf Laboratorium at the University of Utrecht (Biddle \& Kjølbye-Biddle 2001). Terrestrial calibration of these determinations resulted in dates that, in many cases, were either inconsistent with the archaeological evidence, or yielded imprecise calibrated ranges. Notably, dated bones from the charnel appear to fall into two separate groups (Figure 4). One group of at least four different individuals seemed to date from as early as the seventh or eighth century, with the remainder fitting with a ninth-century (C) Antiquity Publications Ltd, 2018 

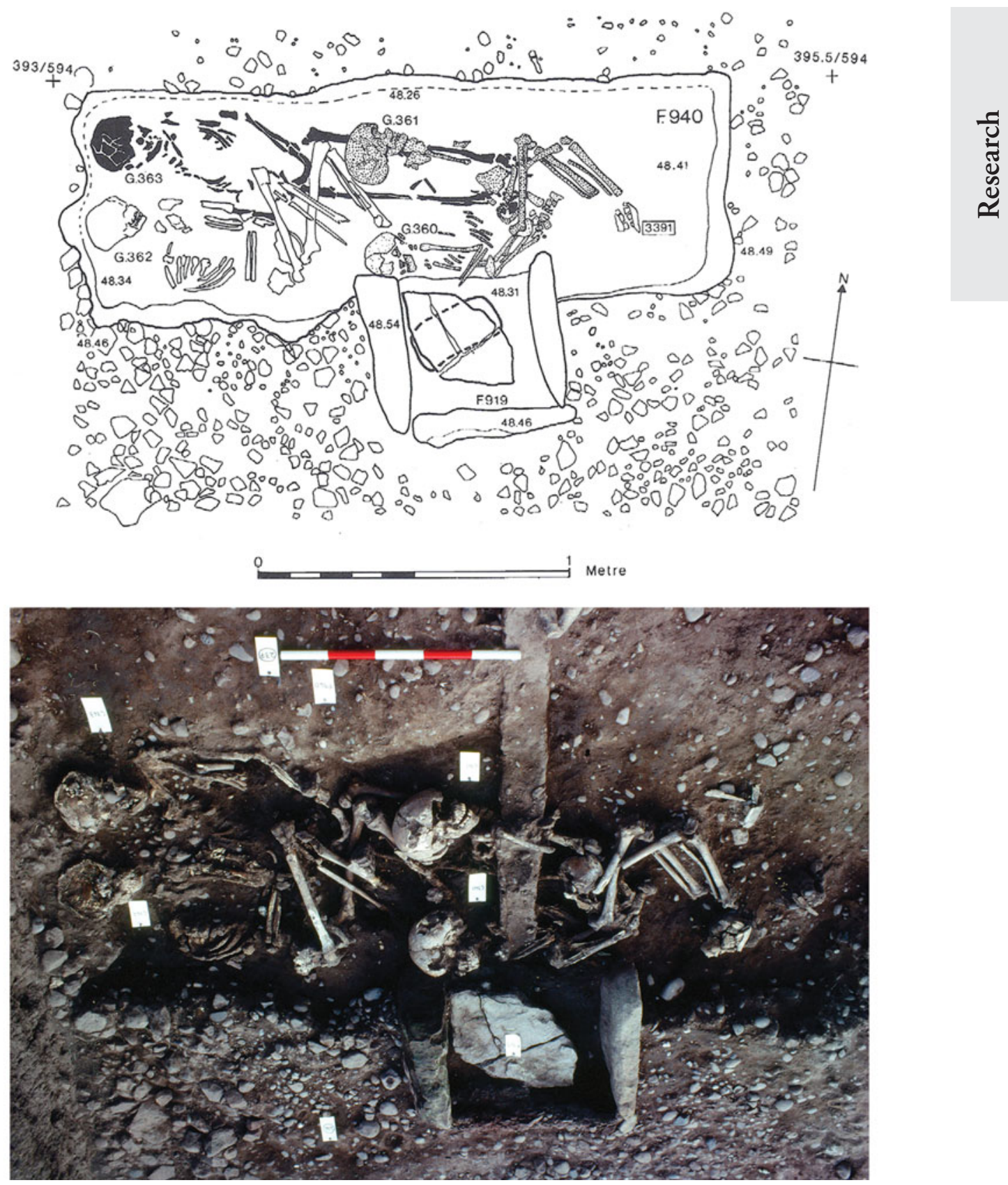

Figure 3. Plan and photograph of the juvenile grave, F940 (@ M. Biddle). 


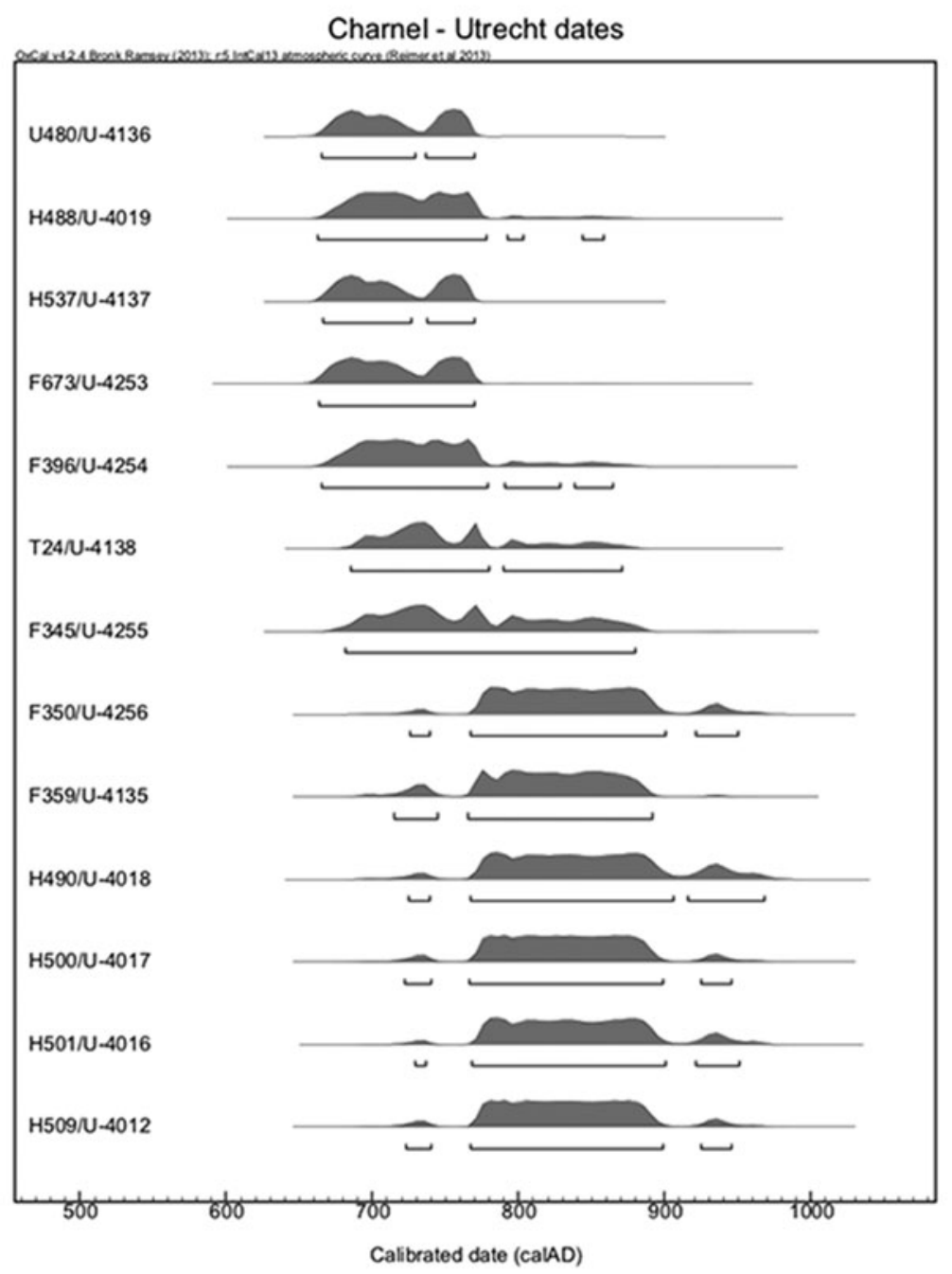

Figure 4. Plot of the terrestrial calibration of the Utrecht radiocarbon dates.

date. This suggested, therefore, that the bones were not all from a single contemporaneous group, making them incompatible with a population derived from the Viking Great Army of AD 873-874. An alternative hypothesis (Richards et al. 2004) suggested that some of the charnel bones may have come from the older cemetery of St Wystan's church, uncovered during the excavation of the ditch for the winter camp in AD 873-874 and reburied beneath the mound in the vicarage garden.

Another explanation for the apparent disparity between the radiocarbon dates and the archaeological evidence may lie in a lack of MRE corrections. ${ }^{14} \mathrm{C}$ is not equally distributed across the biosphere and marine ecological zones. After production, it is incorporated into the terrestrial food chain by being fixed from atmospheric $\mathrm{CO}_{2}$ via photosynthesis. Carbon (C) Antiquity Publications Ltd, 2018 
exchanges in dynamic equilibrium with sea-surface ocean waters, and yet due to the large size of the ocean carbon reservoir and the slow rate of mixing throughout, there is an offset between the ${ }^{14} \mathrm{C}$ concentration in the ocean and that of the atmosphere. This offset averages around 400 years (Aitken 2013). These differences are reflected in consumers and passed on up the food chain. It has been demonstrated elsewhere (e.g. Ascough et al. 2012) that MREs can significantly influence the ${ }^{14} \mathrm{C}$ concentration of radiocarbon dates determined from humans and fauna that may have consumed marine-derived proteins. Similar effects are seen in freshwater contexts such as lakes and rivers (e.g. Cook et al. 2001).

To correct for MREs, a local reservoir value $(\Delta \mathrm{R})$ must be established to take into account any differences between the global average marine reservoir offset and local variations (Cook et al. 2015; Russell et al. 2015). A particular challenge for the Repton material is the determination of an appropriate 'local' value for what appears to be a highly mobile group of people, whose collagen probably represents carbon assimilated from a range of geographic sources. Although the isotope data from the double grave suggests a southern Scandinavian origin for those two men, this relates to their childhood; the collagen dated here pertains to more recent diets over the 10-15 years preceding their death. As historical sources suggest that the Great Army was active in England for at least a decade before arrival in Repton (Swanton 2000), it is uncertain whether Scandinavian reference data would provide accurate $\Delta \mathrm{R}$ values for these individuals.

It is also necessary to estimate the proportion of marine foods in each individual's diet. This can be reconstructed from stable isotope data in a number of ways, all of which are approximations and are associated with varying degrees of confidence (for a review, see Phillips et al. 2014). The simplest methods rely on linear interpolations between endmembers that represent a fully terrestrial or fully marine diet (e.g. Arneborg et al. 1999), whereby isotope data from a given individual are compared against values measured from humans or animals consuming only terrestrial or marine proteins respectively. Both $\delta^{13} \mathrm{C}$ and $\delta^{15} \mathrm{~N}$ can be used in this way, but $\delta^{15} \mathrm{~N}$ values are particularly sensitive to local environmental conditions (Szpak 2014), and can also vary for physiological reasons, such as weaning or nutritional stress (e.g. Fuller et al. 2005). In addition, there may be systematic geographic differences in $\delta^{15} \mathrm{~N}$ values between Scandinavia and the British Isles from the early medieval period, and the input of dietary protein from freshwater food sources can also obscure their interpretation (Cook et al. 2001; Bonsall et al. 2007; Pollard et al. 2012; Chenery et al. 2014). Consequently, we used only $\delta^{13} \mathrm{C}$ values for dietary reconstruction and MRE corrections.

\section{Materials and methods}

\section{Materials}

The new samples (Table 1) were selected to provide a more detailed dating sequence than the previously published dates. Three samples came from burials in cemetery 3 to the north of the church, thought to be contemporaneous with the charnel deposit. These are the Viking double grave (G.511 and G.295) and a grave with five coins dated to AD 872-875 (G.529). Eight samples were selected from within the charnel deposit, which has been dated 


\begin{tabular}{|c|c|c|c|c|c|c|c|c|c|c|c|c|c|}
\hline \multirow{2}{*}{$\begin{array}{l}\text { Grave or } \\
\text { charnel bone } \\
\text { ID }\end{array}$} & \multirow[b]{2}{*}{ Cemetery } & \multicolumn{5}{|c|}{ ORAU } & \multicolumn{3}{|c|}{ Utrecht } & \multirow{2}{*}{$\begin{array}{l}\text { Contextual date } \\
\text { (AD) }\end{array}$} & \multirow[b]{2}{*}{ Sex } & \multirow[b]{2}{*}{ Age } & \multirow[b]{2}{*}{ Species } \\
\hline & & Lab. ID & ${ }^{14} \mathrm{C} \mathrm{BP}$ & $\delta^{15} \mathrm{~N}^{*}$ & $\delta^{13} C^{*}$ & $\%$ marine & Lab. ID & ${ }^{14} \mathrm{C} \mathrm{BP}$ & $\delta^{13} C^{\#}$ & & & & \\
\hline G97 & 1 & OxA-31451 & $1298 \pm 24$ & 10.0 & -19.2 & 21.2 & - & - & - & $700-800$ & $\mathrm{U}$ & juvenile & human \\
\hline G529 & 3 & OxA-12024 & $1281 \pm 27$ & 11.2 & -19.7 & 15.3 & U-4011 & $1193 \pm 30$ & -20.3 & $872-875$ & M & adult & human \\
\hline G511 & 3 & OxA-12023 & $1250 \pm 25$ & 12.3 & -18.6 & 28.2 & U-4020 & $1192 \pm 38$ & -20.0 & 874 or soon after & M & adult & human \\
\hline G295 & 3 & OxA-12004 & $1209 \pm 27$ & 12.0 & -19.0 & 23.5 & - & - & - & 874 or soon after & M & adult & human \\
\hline G.511/7109 & 3 & OxA-14570 & $1215 \pm 29$ & 5.2 & -20.7 & 3.5 & - & - & - & 874 or soon after & - & - & $\begin{array}{c}\text { Sus scrofa } \\
\text { tusk }\end{array}$ \\
\hline G387 & $3 \mathrm{M}$ & OxA-12009 & $1233 \pm 25$ & 10.3 & -18.3 & 31.8 & - & - & - & $900-1000$ & M & adult & human \\
\hline G360 & F.940 & OxA-12005 & $1230 \pm 24$ & 10.0 & -19.7 & 15.3 & - & - & - & 874 or soon after & $\mathrm{U}$ & juvenile & human \\
\hline G361 & F.940 & OxA-12006 & $1193 \pm 25$ & 9.8 & -20.1 & 10.6 & - & - & - & 874 or soon after & $\mathrm{U}$ & juvenile & human \\
\hline G362 & F.940 & OxA-12007 & $1218 \pm 25$ & 11.7 & -20.0 & 11.8 & - & - & - & 874 or soon after & $\mathrm{U}$ & juvenile & human \\
\hline G363 & F.940 & OxA-12008 & $1236 \pm 25$ & 12.2 & -20.5 & 5.9 & - & - & - & 874 or soon after & $\mathrm{U}$ & juvenile & human \\
\hline RF.3391 & F.940 & OxA-12364 & $1199 \pm 27$ & 6.0 & -21.6 & 0 & - & - & - & 874 or soon after & - & - & $\begin{array}{l}\text { Ovis aries } \\
\text { mandible }\end{array}$ \\
\hline $\mathrm{X}-03$ & charnel & OxA-13076 & $1273 \pm 27$ & 11.6 & -18.9 & 24.7 & - & - & - & $873-874$ & $\mathrm{~F}$ & adult & human \\
\hline $\mathrm{X}-17$ & charnel & OxA-31524 & $1256 \pm 28$ & 11.9 & -18.7 & 27.1 & - & - & - & $873-874$ & $\mathrm{~F}$ & adult & human \\
\hline $\mathrm{X}-23$ & charnel & OxA-31449 & $1267 \pm 22$ & 10.5 & -19.1 & 22.4 & - & - & - & $873-874$ & M & adult & human \\
\hline $\mathrm{X}-70$ & charnel & OxA-31450 & $1217 \pm 28$ & 11.7 & -18.2 & 32.9 & - & - & - & $873-874$ & M & adult & human \\
\hline H-537 & charnel & OxA-31611 & $1333 \pm 25$ & 10.7 & -18.7 & 26.7 & U-4137 & $1293 \pm 22$ & -19.9 & $873-874$ & $\mathrm{U}$ & adult & human \\
\hline U-480 & charnel & OxA-12001 & $1271 \pm 26$ & 10.2 & -19.2 & 21.2 & U-4136 & $1292 \pm 23$ & -20.2 & $873-874$ & $\mathrm{U}$ & adult & human \\
\hline F359 & charnel & OxA-12002 & $1223 \pm 25$ & 10.4 & -19.1 & 22.4 & U-1435 & $1207 \pm 27$ & -20.0 & $873-874$ & $\mathrm{U}$ & adult & human \\
\hline F391 & charnel & OxA-12003 & $1230 \pm 25$ & 10.7 & -18.9 & 24.7 & - & - & - & $873-874$ & $\mathrm{U}$ & adult & human \\
\hline
\end{tabular}


to $\mathrm{AD} 872-874$ using numismatic evidence. To constrain the end date of the charnel, one sample (G.387) was selected from cemetery $3 \mathrm{M}$, which is stratigraphically later than the charnel mound. The four young individuals from feature 940 (G.360-63) were also dated. The sheep jaw included in this grave provides a ${ }^{14} \mathrm{C}$ date from an animal with a purely terrestrial diet. Finally, a sample from the seventh- to eighth-century monastic cemetery (cemetery 1) was also included (G.97). In order to compare the validity of the former ${ }^{14} \mathrm{C}$ dates, five of the selected samples were taken from individuals previously dated in Utrecht.

\section{Methods}

Between 2002 and 2015, bone samples of approximately 500-1000mg dry weight were AMS dated at the Oxford Radiocarbon Accelerator Unit (ORAU), with collagen prepared following the methods outlined in Bronk Ramsey et al. (2004). Carbon and nitrogen isotopic compositions were determined using GC-C-IRMS on an aliquot of the same prepared collagen used for ${ }^{14} \mathrm{C}$ analysis, and are reported using standard delta notation relative to the reference standards Vienna Pee Dee Belemnite (V-PDB) and atmospheric nitrogen (AIR) for $\delta^{13} \mathrm{C}$ and $\delta^{15} \mathrm{~N}$ respectively.

OxCal v.4.2 was used to calibrate the radiocarbon determinations using the IntCal13 atmospheric curve and Marine13 marine calibration curve (Reimer et al. 2013). A local reservoir correction $\Delta \mathrm{R}$ value of $-47 \pm 52{ }^{14} \mathrm{C}$ years was used for all samples, after the weighted mean value for Scotland determined by Russell et al. (2015), as no similar values are available for England. We also assessed relative differences between this and other possible $\Delta \mathrm{R}$ values to test whether the conclusions that we reached still held true.

Stable isotope data were used to provide marine dietary estimates for each individual based on linear interpolation of bulk $\delta^{13} \mathrm{C}$ collagen values, using the following equation to calculate the fraction of marine dietary protein $\left(\mathrm{f}_{\mathrm{m}}\right)$ in any given individual $n$

$$
\mathrm{f}_{\mathrm{m}}=\frac{\delta^{13} \mathrm{C}_{\mathrm{n}}-\delta^{13} \mathrm{C}_{\text {terr }}}{\delta^{13} \mathrm{C}_{\mathrm{mar}}-\delta^{13} \mathrm{C}_{\mathrm{terr}}}
$$

where $\delta^{13} \mathrm{C}_{\mathrm{n}}$ is the measured value for sample $n$, and $\delta^{13} \mathrm{C}_{\text {terr }}$ and $\delta^{13} \mathrm{C}_{\mathrm{mar}}$ correspond to the isotopic values of fully terrestrial and fully marine end-members respectively. There are no known sources of $\mathrm{C}_{4}$ foods, which can cause elevated $\delta^{13} \mathrm{C}$ values in consumers, from medieval contexts in Northern Europe (Kosiba et al. 2007). Variation in $\delta^{13} \mathrm{C}$ values should therefore relate entirely to differing consumption of marine food sources. For a terrestrial end-member, a $\delta^{13} \mathrm{C}$ value of $-21.0 \%$ was used, in accordance with values used elsewhere (Arneborg et al. 1999; Cook et al. 2015). This is close to the $\delta^{13} \mathrm{C}$ value measured in the sheep jaw from feature F940 (-21.6\%o), when a 1\%o offset for fractionation between diet and consumer is taken into account (Ambrose et al. 1997). A reliable marine end-member value is more difficult to obtain because there are no representative fully marine consumers from Repton. Instead, the reference value of $-12.5 \%$, suggested by Arneborg et al. (1999) in a study from Greenland, was used.

Quantifying the error associated with mixing models is complicated, as a wide range of both physiological and methodological factors affect the estimates (Hedges 2004; Cook et al. 2015). Although methods for quantifying and propagating errors have been 
demonstrated elsewhere (e.g. Phillips \& Gregg 2001), these may be less applicable to an archaeological context where the accuracy of the dietary end-members is uncertain. Therefore, despite compromising on precision, we add an unquantified general uncertainty of $\pm 10 \%$ to each marine estimate here in accordance with common practice (Cook et al. 2015). Where possible, Bayesian modelling was used to constrain calibrated ${ }^{14} \mathrm{C}$ dates further by employing stratigraphic information and associated dated artefacts.

\section{Results and discussion}

With the exception of one sample (G. 529$),{ }^{14} \mathrm{C}$ dates of material previously dated at Utrecht agreed within instrumental uncertainty for all samples, indicating the validity of the former ${ }^{14} \mathrm{C}$ determinations. It is not currently possible to correct for MREs in the full Utrecht dataset, as independently determined stable isotope data are not available from those samples. The published $\delta^{13} \mathrm{C}$ values (Biddle \& Kjølbye-Biddle 2001) were obtained via the AMS measurements and were probably affected by some form of fractionation associated with the sample preparation or measurement process. This is evidenced by comparing the Utrecht AMS and ORAU IRMS $\delta^{13} \mathrm{C}$ values of the replicated samples, which gives an average difference of $1.1 \%$ (range $0.9-1.4 \%$ ). This corresponds to an average variation in marine consumption of $12.9 \pm 10 \%$, which suggests that the Utrecht $\delta^{13} \mathrm{C}$ values cannot be reliably used for MRE corrections.

Our $\delta^{13} \mathrm{C}$ interpolations demonstrate some degree of marine protein consumption in all individuals, ranging from $5.9 \pm 10 \%$ to $32.9 \pm 10 \%$ (Table 1). As seen in the Utrecht dataset, terrestrial calibrations demonstrate that the age ranges of all samples are affected by a plateau in the calibration curve, giving dates that span the eighth and ninth centuries $\mathrm{AD}$ at $95.4 \%$ certainty (Table 2). Precision is further affected by the MRE corrections, whereby the necessary uncertainties applied to our calculations make the calibrated age ranges even wider. For several of the graves, however, contextual and stratigraphic evidence, combined with Bayesian modelling, significantly refines the age estimates.

We evaluated our choice of $\Delta \mathrm{R}$ value to test the effect that this had on our conclusions by calibrating the date for G.529, which has a terminus post quem (TPQ) date of AD 872 (see below), using ten different $\Delta \mathrm{R}$ values from a range of other Northern European locations. Although the range of reference values is high (from $-131 \pm 40$ to $83 \pm 48$ ), the results show relatively little variation and are all consistent with the archaeologically derived date (Table S1). This demonstrates the robustness of our chosen value.

\section{Individual and double graves}

The sample from the monastic cemetery (G.97) is consistent with the archaeologically derived date of between the seventh and eighth centuries $\mathrm{AD}$; this is true for both the terrestrial and marine calibrations (AD 663-769 and AD 686-885 respectively at $95.4 \%$ certainty).

Grave 529 provides the clearest evidence of the need for marine reservoir corrections at Repton. The sample yielded an uncalibrated ${ }^{14} \mathrm{C}$ date of $1281 \pm 27 \mathrm{BP}$, which provides a terrestrial calibration of $\mathrm{AD} 670-770$ at $95.4 \%$ certainty. This individual was buried with five silver pennies, two of Burghred and three of Alfred, dated to no earlier than (C) Antiquity Publications Ltd, 2018 
Table 2. Calibrated ${ }^{14} \mathrm{C}$ dates, using both terrestrial and mixed marine/terrestrial calibration curves.

\begin{tabular}{|c|c|c|c|c|c|}
\hline $\begin{array}{l}\text { Grave or } \\
\text { charnel bone } \\
\text { ID }\end{array}$ & Cemetery & Lab. ID & ${ }^{14} \mathrm{C} \mathrm{BP}$ & $\begin{array}{c}\text { Terrestrial } \\
\text { calibration }(\mathrm{cal} \\
\text { years } \mathrm{AD}, 95.4 \% \\
\text { certainty) }\end{array}$ & $\begin{array}{c}\text { Mixed } \\
\text { marine/terrestrial } \\
\text { calibration }(\mathrm{cal} \\
\text { years } \mathrm{AD}, 95.4 \% \\
\text { certainty) }\end{array}$ \\
\hline G97 & 1 & OxA-31451 & $1298 \pm 24$ & $663-769$ & $686-885$ \\
\hline G529 & 3 & OxA-12024 & $1281 \pm 27$ & $670-770$ & 690-939 \\
\hline G511 & 3 & OxA-12023 & $1250 \pm 25$ & $677-866$ & $772-975$ \\
\hline G295 & 3 & OxA-12004 & $1209 \pm 27$ & $715-890$ & $773-972$ \\
\hline G.511/7109 & 3 & OxA-14570 & $1215 \pm 29$ & $695-889$ & - \\
\hline G387 & $3 \mathrm{M}$ & OxA-12009 & $1233 \pm 25$ & $689-879$ & 778-990 \\
\hline G360 & F.940 & OxA-12005 & $1230 \pm 24$ & $690-881$ & $720-966$ \\
\hline G361 & F.940 & OxA-12006 & $1193 \pm 25$ & $730-893$ & $770-980$ \\
\hline G362 & F.940 & OxA-12007 & $1218 \pm 25$ & 696-887 & $720-968$ \\
\hline G363 & F.940 & OxA-12008 & $1236 \pm 25$ & $687-877$ & $682-894$ \\
\hline RF.3391 & F.940 & OxA-12364 & $1199 \pm 27$ & $721-893$ & - \\
\hline $\mathrm{X}-03$ & charnel & OxA-13076 & $1273 \pm 27$ & $665-775$ & $694-951$ \\
\hline$X-17$ & charnel & OxA-31524 & $1256 \pm 28$ & $672-866$ & $724-977$ \\
\hline $\mathrm{X}-23$ & charnel & OxA-31449 & $1267 \pm 22$ & $677-773$ & $693-948$ \\
\hline $\mathrm{X}-70$ & charnel & OxA-31450 & $1217 \pm 28$ & $696-888$ & $780-1017$ \\
\hline H-537 & charnel & OxA-31611 & $1333 \pm 25$ & $649-765$ & $675-876$ \\
\hline U-480 & charnel & OxA-12001 & $1271 \pm 26$ & $667-775$ & $690-942$ \\
\hline F359 & charnel & OxA-12002 & $1223 \pm 25$ & $695-884$ & $773-980$ \\
\hline F391 & charnel & OxA-12003 & $1230 \pm 25$ & $690-881$ & $773-981$ \\
\hline
\end{tabular}

AD 873 (Biddle et al. 1986). This TPQ date makes the terrestrial calibration at the very least 100 years too early. With an estimated marine dietary input of $15.3 \pm 10 \%$, a mixed marine/terrestrial calibration gives a date of AD 690-939 (95.4\% certainty), which is consistent with the coin date. Taking the TPQ into account, the grave can be further constrained to AD 873-939.

A similar result is evident from grave G.387 from cemetery 3M. From its location, this grave must post-date the AD 872-874 date of the coins found among the charnel deposit, as it is stratigraphically later than the construction of the mound. From an uncalibrated ${ }^{14} \mathrm{C}$ determination of $1233 \pm 25 \mathrm{BP}$, a terrestrial calibration yields a date of AD 689879 at $95.4 \%$ certainty. While not entirely unfeasible, this result is inconsistent with the archaeologically derived date of AD 900-1000 for cemetery 3M. An MRE correction using an estimated marine dietary input of $31.8 \pm 10 \%$ gives a calibrated age of AD 778-990, which can be limited to AD 872-990 from the coin finds described above. Therefore, with the appropriate correction, this date is actually in good agreement with the archaeological evidence.

Individually, the fully terrestrial calibrations of the double grave of G.511 and G.295 give dates of AD 677-866 and AD 715-890 respectively (95.4\% confidence). The early date for G.511 is inconsistent with our current understanding of the historical and archaeological evidence. The grave goods leave little doubt as to the Scandinavian cultural identity of 


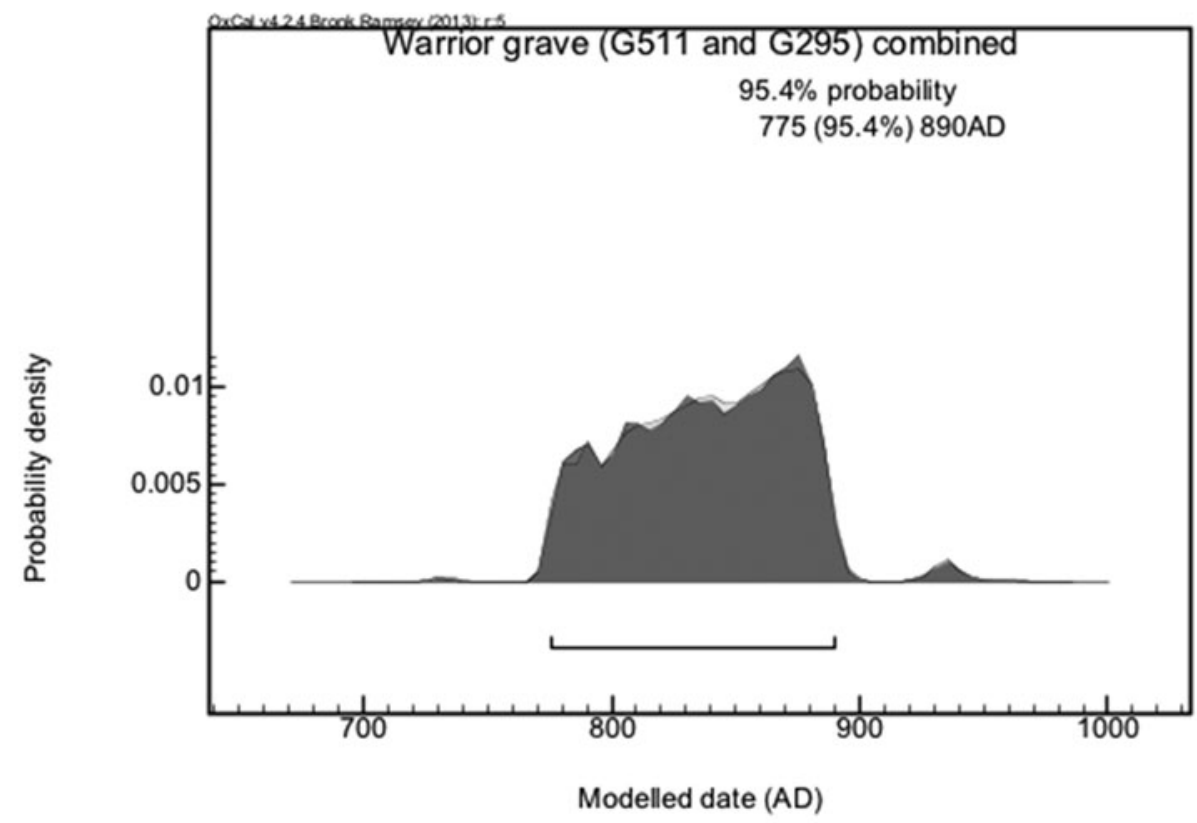

Figure 5. Plot of the combined mixed marinelterrestrial calibration of G.511, G.295 and the boar's tusk.

this individual, yet a date before AD 873 seems unlikely, as there is no evidence for a Scandinavian presence in Repton prior to this date. MRE corrections based on marine diet amounts of $28.2 \pm 10 \%$ and $23.1 \pm 10 \%$, however, give calibrated dates of AD 772-975 and AD 773-972 for G.511 and G.295 respectively. A boar tusk buried with G.511 yielded a calibrated date of AD 695-889, assuming a terrestrial calibration. As the three samples are clearly coeval, we can apply OxCal's Combine function to obtain a modelled date of $\mathrm{AD}$ $778-886\left(95.4 \%\right.$ confidence, $A_{\text {comb }}=116.4 \%$, Figure 5). Assuming a TPQ of AD 873 on the basis of the historical evidence narrows the date for the double grave to AD 873-886.

\section{Juvenile grave, feature 940}

Terrestrial calibrations of all four juveniles fall between $\mathrm{AD} 687$ and 893 at $95.4 \%$ certainty, and the sheep jaw from the same deposit dates to AD 721-893. Marine foods appear to have formed a relatively small part of the diet of these individuals (ranging from 5.915.3 $10 \%$ ), yet MRE corrections move the calibrated dates to between AD 695 and 990 . As the deposition of the four individuals and the sheep jaw was clearly simultaneous, we can use OxCal's Combine function to constrain a modelled and MRE-corrected date of AD 778-885 (Figure 6).

The juvenile grave is located just outside the edge of the stone kerb surrounding the charnel mound. There is no evidence that any of the graves in cemetery $3 \mathrm{M}$ pre-date the construction of the mound, and the grave cut of F940 carefully follows the alignment of the remaining burials. For this reason, it is highly unlikely that the grave pre-dates the $\mathrm{AD}$ 872 TPQ date for the construction of the mound. Therefore, we can tentatively accept (C) Antiquity Publications Ltd, 2018 


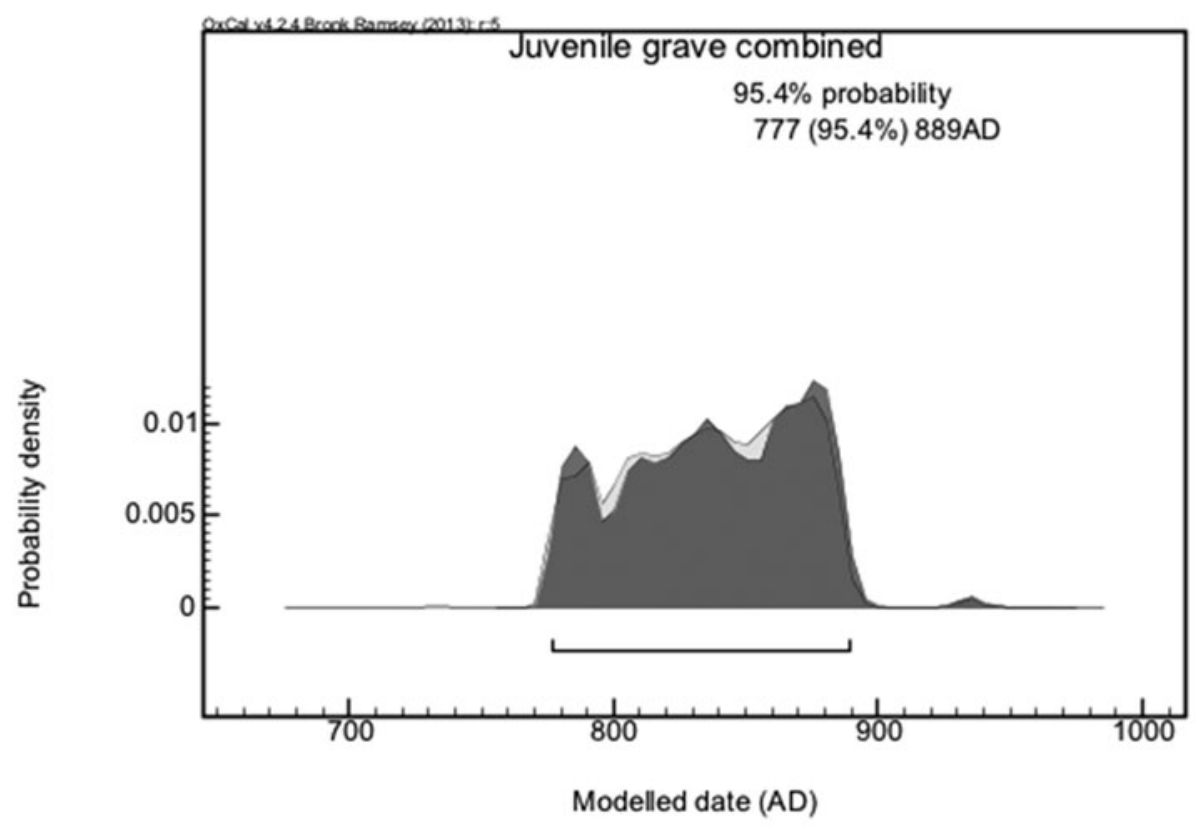

Figure 6. Plot of the combined mixed marine/terrestrial calibration of the burials in the juvenile grave (F.940).

this TPQ for the juvenile grave, which provides us with a very narrow date range of $\mathrm{AD}$ 872-885.

\section{Charnel}

With fully terrestrial calibrations, the charnel samples fall in a similar grouped pattern to the Utrecht dates, with some encompassing the presumed late ninth-century date, and others substantially pre-dating it (Figure 4). It is clear from the $\delta^{13} \mathrm{C}$ values $(-19.2$ to $-18.2 \%$; Table 1) that some individuals had considerable marine dietary input, up to a maximum of $32.9 \pm 10 \%$ for sample X70. Individual MRE corrections shift the latest possible date for all samples to at least the late ninth, if not the tenth, century AD (Table 2; Figure 7). As such, a date of AD 872-874, as suggested by the archaeological and numismatic evidence, is consistent with all the bone samples dated here. If, as the archaeological context indicates, this is one deposit, then we can further apply a Combine function, on the assumption that the remains are coeval. This provides a combined date of AD 779-887 for the charnel deposit (95.4\% certainty, $\left.\mathrm{A}_{\text {comb }}=79.9 \%\right)$.

It is important to note that although the calibrated samples from cemeteries 1 and 3 are consistent with the archaeologically derived dates, the age ranges are wide due to a plateau in the terrestrial calibration curve. This is also the case for the charnel deposit. Therefore, the dates encompass both the period of the historically attested Viking presence in Repton, and the latest period of monastic use of the site. To model the effect of this plateau, OxCal's R_Simulate function can randomly generate calibrated distributions, assuming a true age of $\mathrm{AD} 873$. This shows that the ages equivalent to $\mathrm{AD} 873$ range widely, but that discerning 


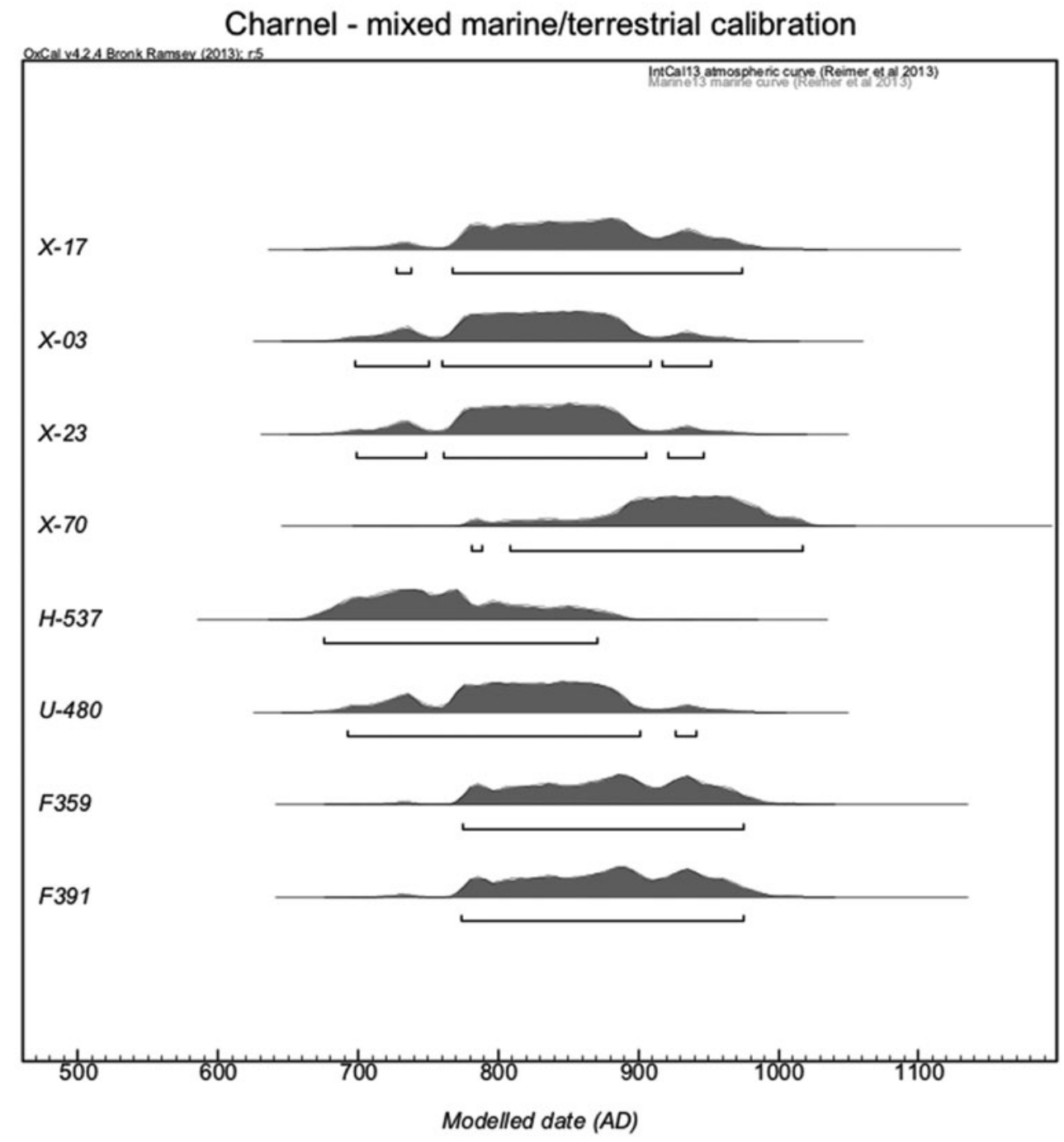

Figure 7. Plot of the combined mixed marine/terrestrial calibration of the new charnel samples.

samples from $\mathrm{AD} 873-874$ from earlier periods, such as around $\mathrm{AD} 750$ or $\mathrm{AD} 800$, is possible. The plateau in the calibration curve artificially spreads ages to be too old, rather than too young. It is notable that the graves in cemetery 3, which yielded Viking Age grave goods, share a similar spread of calibrated date ranges with the charnel deposit.

\section{Summary and conclusions}

The data presented here clearly demonstrate that the apparent groupings seen in the previously published charnel ${ }^{14} \mathrm{C}$ dataset are a result of MREs, rather than a reflection of the true age of the samples. Significantly, our calibrations show that the deposit is fully (C) Antiquity Publications Ltd, 2018 
consistent with a single event dating to the late ninth century AD. Previous suggestions that some of the skeletal remains in the charnel originated from the monastic cemeteries, disinterred during the construction of the D-shaped enclosure, are founded entirely on the earlier dates previously accepted for some of the bones (Richards et al. 2004). The current results show that the radiocarbon dates do not support this line of argument.

Importantly, the very narrow date range of AD 872-885 for the juvenile grave helps support a Viking association for the charnel. Although an interpretation of this grave as sacrificial is uncertain, the deliberate arrangement of these four individuals, the sheep jaw and the possible grave marker in close proximity to the edge of the mound attests to its relationship to the charnel.

In summary, the new radiocarbon dates show that:

- MRE calibrations are vital for accurately dating the Repton material - the early dates from the charnel were caused by a lack of such corrections.

- The charnel is consistent with a single deposit in the late ninth century.

- The warrior double grave and the juvenile grave can both be constrained to narrow date ranges (AD 873-886 and $\mathrm{AD} 872-885$ respectively), which are consistent with the archaeological and historical evidence.

The new data presented here fully support the hypothesis that the Repton charnel contains the remains of members of the Viking Great Army, and further confirms the chronology of the Viking use of St Wystan's church and its surroundings for burial. In addition to helping understand the movements of the Great Army and the subsequent settlement of a Scandinavian population in England, this study has broader implications in emphasising the importance of applying MRE corrections to radiocarbon dates from human bone. Isotope analysis of human tissues is becoming increasingly standard practice for studying geographic origins and aDNA methods are improving rapidly. This means that there is now greater potential than ever for the range of information that can be obtained from human remains alone. For charnels and other types of secondary burial, as well as other scenarios where context and stratigraphy are lacking or unclear, MRE corrections are essential. Sites with multiple burials and commingled remains may contain evidence for large populations; bioarchaeological data can therefore be used to inform about population dynamics or migration events. Similarly, for cases where radiocarbon dates seem anomalous or incompatible with other forms of evidence, correcting for MREs is strongly recommended. As the Repton example shows, such datasets benefit from reassessment if these corrections have not previously been applied, as failure to do so may lead to inaccurate or even erroneous interpretations.

\section{Acknowledgements}

This research was supported through an AHRC doctoral grant (AH/K502947/1) awarded to C.J. The Utrecht ${ }^{14} \mathrm{C}$ dates were funded by the BBC, and the Oxford dates through an ORAU facility grant. We are grateful to Richard Evershed and Tim Knowles for early discussions on the dataset, and would also like to acknowledge the contributions of the late Birthe Kjølbye-Biddle, whose efforts to excavate, plan and interpret the graves described here were fundamental to this paper and for ongoing research on Repton. 


\section{Supplementary material}

To view supplementary material for this article, please visit https://doi.org/10.15184/aqy. 2017.196

\section{References}

Aitken, M.J. 2013. Science-based dating in archaeology. London: Routledge.

Ambrose, S.H., B.M. Butler, D.B. Hanson, R.L. Hunter-Anderson \& H.W. Krueger. 1997. Stable isotopic analysis of human diet in the Marianas Archipelago, western Pacific. American Journal of Physical Anthropology 104: 343-61. https://doi.org/10.1002/(SICI)10968644(199711)104:3<343::AIDAJPA5 $>3.0 . \mathrm{CO} ; 2-\mathrm{W}$

Arneborg, J., J. Heinemeier, N. Lynnerup, H.L. NiELSEN, N. Rud \&

A.E. SveinbjörnsdótTir. 1999. Change of diet of the Greenland Vikings determined from stable carbon isotope analysis and ${ }^{14} \mathrm{C}$ dating of their bones. Radiocarbon 41: 157-68.

https://doi.org/10.1017/S0033822200019512

Ascough, P.L., M.J. Church, G.T. Cook, E. Dunbar, H. Gestsdóttir, T.H. McGovern, A.J. Dugmore, A. FriĐriksson \& K.J. Edwards. 2012. Radiocarbon reservoir effects in human bone collagen from northern Iceland. Journal of Archaeological Science 39: 2261-71. https://doi.org/10.1016/j.jas.2012.02.012

Biddle, M. \& B. KJølbye-Biddle. 1985. The Repton Stone. Anglo-Saxon England 14: 233-92. https://doi.org/10.1017/S0263675100001368

- 1992. Repton and the Vikings. Antiquity 66: 36-51. https://doi.org/10.1017/S0003598X00081023

- 2001. Repton and the 'great heathen army', 873-4, in J. Graham-Campbell (ed.) Vikings and the Danelaw: select papers from the Proceedings of the Thirteenth Viking Congress, Nottingham and York, 21-30 August 1997: 45-96. Oxford: Oxbow.

Biddle, M., C. Blunt, B. Kjølbye-Biddle, M. Metcalf \& H. Pagan. 1986. Coins of the Anglo-Saxon period from Repton, Derbyshire: II. The British Numismatic Journal 56: 15-34.

Bigsby, R. 1854. Historical and topographical description of Repton, in the County of Derby: comprising an incidental view of objects of note in its vicinity. London: Woodfall.

Bonsall, C., G. Cook, R. Hedges, T. Higham, C. Pickard \& I. Radovanović. 2007. Radiocarbon and stable isotope evidence of dietary change from the Mesolithic to the Middle Ages in the Iron Gates: new results from Lepenski Vir. Radiocarbon 46: 293-300. https://doi.org/10.1017/S0033822200039606
Bronk Ramsey, C., T. Higham, A. Bowles \& R. Hedges. 2004. Improvements to the pretreatment of bone at Oxford. Radiocarbon 46: 155-63. https://doi.org/10.1017/S0033822200039473

Budd, P., A. Millard, C. Chenery, S. Lucy \& C. Roberts. 2004. Investigating population movement by stable isotope analysis: a report from Britain. Antiquity 78: 127-41. https://doi.org/10.1017/S0003598X0009298X

Chenery, C., A.L. Lamb, J. Evans, H.J. Sloane \& C. Stewart. 2014. Appendix 3: isotope analysis of individuals from the Ridgeway Hill mass grave, in L. Loe, A. Boyle, H. Webb \& D. Score (ed.) 'Given to the ground': a Viking Age mass grave on Ridgeway Hill, Weymouth. Dorchester: Dorset Natural History and Archaeological Society.

Cook, G.T., C. Bonsall, R.E. Hedges, K. McSweeney, V. Boronean \& P.B. Pettitt. 2001. A freshwater diet-derived C-14 reservoir effect at the Stone Age sites in the Iron Gates gorge. Radiocarbon 43: 453-60. https://doi.org/10.1017/S0033822200038327

Cook, G.T., P. Ascough, C. Bonsall, W. Hamilton, N. Russell, K. Sayle, E. Scott \& J. Bownes. 2015. Best practice methodology for ${ }^{14} \mathrm{C}$ calibration of marine and mixed terrestrial/marine samples. Quaternary Geochronology 27: 164-71. https://doi.org/10.1016/j.quageo.2015.02.024

DEGG, S. 1727. An account of an humane skeleton of an extraordinary size, found in a repository at Repton in Derby-shire, together with some examples of long life, communicated by Simon Degg, MD \& FRS. Philosophical Transactions (1683-1775) 35: 363-65.

Fuller, B.T., J.L. Fuller, N.E. Sage, D.A. Harris, T.C. O’Connell \& R.E. Hedges. 2005. Nitrogen balance and $\delta^{15} \mathrm{~N}$ : why you're not what you eat during nutritional stress. Rapid Communications in Mass Spectrometry 19: 2497-506. https://doi.org/10.1002/rcm.2090

Hadley, D.M. 2006. The Vikings in England. Settlement, society and culture. Manchester: Manchester University Press.

Hadley, D., J. Richards, G. Perry, D. Mahoney Swales, E. Craig-Atkins, S. Stein \& A. Woods. 2016. The winter camp of the Viking Great Army, AD 872-3, Torksey, Lincolnshire. Antiquaries Journal 96: 23-67. https://doi.org/10.1017/S0003581516000718

(C) Antiquity Publications Ltd, 2018 
Hedges, R.E.M. 2004. Isotopes and red herrings: comments on Milner $e t$ al. and Lidén $e t$ al. Antiquity 78: 34-37. https://doi.org/10.1017/S0003598X00092905

Kershaw, J. \& E.C. Røyrvik. 2016. The 'People of the British Isles' Project and Viking settlement in England. Antiquity 90: 1670-80. https://doi.org/10.15184/aqy.2016.193

Kosiba, S.B., R.H. Түкот \& D. Carlsson. 2007. Stable isotopes as indicators of change in the food procurement and food preference of Viking Age and early Christian populations on Gotland (Sweden). Journal of Anthropological Archaeology 26: 394-411. https://doi.org/10.1016/j.jaa.2007.02.001

Leslie, S., B. Winney, G. Hellenthal, D. Davison, A. Boumertit, T. Day, K. Hutnik, E.C. Røyrvik, B. Cunliffe \& D.J. Lawson. 2015. The fine-scale genetic structure of the British population. Nature 519: 309-14. https://doi.org/10.1038/nature14230

Pagan, H. 1986. The coins from the mass-burial, in M. Biddle, B. Kjølbye-Biddle, J.P. Northover \& H. Pagan, Coins of the Anglo-Saxon period from Repton, Derbyshire: 1. A parcel of pennies from a mass-burial associated with the Viking wintering at Repton in 873-4, in M.A.S. Blackburn (ed.) Anglo-Saxon monetary history. Studies in memory of Michael Dolley: 115-19. Leicester: Leicester University Press.

Phillips, D.L. \& J.W. Gregg. 2001. Uncertainty in source partitioning using stable isotopes. Oecologia 127: 171-79. https://doi.org/10.1007/s004420000578

Phillips, D.L., R. Inger, S. Bearhop, A.L. Jackson, J.W. Moore, A.C. Parnell, B.X. Semmens \& E.J. WARD. 2014. Best practices for use of stable isotope mixing models in food-web studies. Canadian Journal of Zoology 92: 823-35. https://doi.org/10.1139/cjz-2014-0127

Pollard, A.M., P. Ditchfield, E. Piva, S. Wallis, C. Falys \& S. Ford. 2012. 'Sprouting like cockle amongst the wheat': the St Brice's Day massacre and the isotopic analysis of human bones from St John's College, Oxford. Oxford Journal of Archaeology 31: 83-102. https://doi.org/10.1111/j.14680092.2011.00380.x

Redmond, A.Z. 2007. Viking burial in the North of England: study of contact, interaction and reaction between Scandinavian migrants with resident groups, and the effect of immigration on aspects of cultural continuity. Oxford: Hedges.
Reimer, P.J., E. Bard, A. Bayliss, J.W. Beck, P.G. Blackwell, C. Bronk Ramsey, C.E. Buck, H. Cheng, R.L. Edwards, M. Friedrich, P.M. Grootes, T.P. Guilderson, H. Haflidason, I. Hajdas, C. Hatté, T.J. Heaton, D.L. Hoffmann, A.G. Hogg, K.A. Hughen, K.F. Kaiser, B. Kromer, S.W. Manning, M. Niu, R.W. Reimer, D.A. Richards, E.M. ScotT, J.R. Southon, R.A. Staff, C.S.M. Turney $\&$ J. van Der Plicht. 2013. IntCal13 and Marine13 radiocarbon age calibration curves $0-50,000$ years cal BP. Radiocarbon 55: 1869-87.

http://dx.doi.org/10.2458/azu_js_rc.55.16947

Richards, J.D. 2002. The case of the missing Vikings: Scandinavian burial in the Danelaw, in S. Lucy \& A.J. Reynolds (ed.) Burial in early medieval England and Wales. London: Society for Medieval Archaeology.

Richards, J.D., P. Beswick, J. Bond, M. Jecock, J. McKinley, S. Rowland \& F. Worley. 2004. Excavations at the Viking barrow cemetery at Heath Wood, Ingleby, Derbyshire. The Antiquaries Journal 84: 23-116. https://doi.org/10.1017/S0003581500045819

Russell, N., G.T. Cook, P.L. Ascough \& E.M. Scotт. 2015. A period of calm in Scottish seas: a comprehensive study of $\Delta R$ values for the northern British Isles coast and the consequent implications for archaeology and oceanography. Quaternary Geochronology 30 (part A): 34-41. http://doi.org/10.1016/j.quageo.2015.08.001

Sawyer, P.H. 1957. The density of the Danish settlement in England. University of Birmingham Historical Journal VI: 1-17.

- 1962. The age of the Vikings. London: Edward Arnold

Swanton, M. 2000. The Anglo-Saxon chronicle. London: Phoenix.

SzPaK, P. 2014. Complexities of nitrogen isotope biogeochemistry in plant-soil systems: implications for the study of ancient agricultural and animal management practices. Frontiers in Plant Science 5: article no. 288 https://doi.org/10.3389/fpls.2014.00288

TAYlOR, H. 1989. St Wystan's church, Repton. A guide and history. Derby: J.W. Simpson.

Received: 27 November 2016; Accepted: 28 February 2017; Revised: 4 April 2017 